Article

\title{
Rosmarinic Acid Methyl Ester Inhibits LPS-Induced NO Production via Suppression of MyD88- Dependent and -Independent Pathways and Induction of HO-1 in RAW 264.7 Cells
}

\author{
Yangkang So ${ }^{1,2}$, Seung Young Lee ${ }^{3}$, Ah-Reum Han ${ }^{1}$, Jin-Baek Kim ${ }^{1}$, Hye Gwang Jeong ${ }^{2}$ \\ and Chang Hyun Jin ${ }^{1, *}$ \\ 1 Advanced Radiation Technology Institute, Korea Atomic Energy Research Institute, Jeongeup-si, \\ Jeollabuk-do 56212, Korea; yangkang@kaeri.re.kr (Y.S.); arhan@kaeri.re.kr (A.-R.H.); \\ jbkim74@kaeri.re.kr (J.-B.K.) \\ 2 College of Pharmacy, Chungnam National University, Daejeon, Chungcheongnam-do 34134, Korea; \\ hgjeong@cnu.ac.kr \\ 3 Freshwater Bioresources Utilization Division, Nakdonggang National Institute of Biological Resources, \\ Sangju-si, Gyeongsangbuk-do 37242, Korea; nplsy001@nnibr.re.kr \\ * Correspondence: chjin@kaeri.re.kr; Tel.: +82-63-570-3162; Fax: +82-63-570-3813
}

Academic Editor: Norbert Latruffe

Received: 12 July 2016; Accepted: 11 August 2016; Published: 18 August 2016

\begin{abstract}
In this study, we investigated the anti-inflammatory effect of rosmarinic acid methyl ester (RAME) isolated from a mutant cultivar of Perilla frutescens (L.) Britton. We found that RAME inhibits lipopolysaccharide (LPS)-induced nitric oxide (NO) production, with an $\mathrm{IC}_{50}$ of $14.25 \mu \mathrm{M}$, in RAW 264.7 cells. RAME inhibited the LPS-induced expression of pro-inflammatory cytokines including interleukin (IL)-1 $\beta$, IL-6, IL-10, monocyte chemoattractant protein-1, interferon- $\beta$, and inducible nitric oxide synthase (iNOS). Moreover, RAME suppressed the activation of nuclear factor kappa B. These results suggest that the downregulation of iNOS expression by RAME was due to myeloid differentiation primary response gene 88 (MyD88)-dependent and -independent pathways. Furthermore, RAME induced the expression of heme oxygenase-1 (HO-1) through activation of nuclear factor-erythroid 2-related factor 2. Treatment with tin protoporphyrin, an inhibitor of HO-1, reversed the RAME-induced suppression of NO production. Taken together, RAME isolated from P. frutescens inhibited NO production in LPS-treated RAW 264.7 cells through simultaneous induction of HO-1 and inhibition of MyD88-dependent and -independent pathways.
\end{abstract}

Keywords: Perilla frutescens; anti-inflammation; rosmarinic acid methyl ester; MyD88-dependent and -independent pathways; heme oxygenase-1

\section{Introduction}

Inflammation, involved in the non-specific immune system, occurs in response to bodily injury and is required for the continuation of health in the presence of bacterial and viral infections [1]. Acute and chronic inflammation can prove harmful, contributing to the pathogenesis of a variety of diseases including inflammatory bowel disease, multiple sclerosis, atherosclerosis, arthritis, and asthma [2,3]. Macrophages play an important role in inflammatory diseases related to over-production of inflammatory mediators including interleukin (IL)-1 $\beta$, IL-6, IL-10, monocyte chemoattractant protein (MCP)-1, tumor necrosis factor (TNF)- $\alpha$ reactive oxygen species (ROS), and nitric oxide (NO) $[4,5]$. Nitric oxide synthase (NOS), which is responsible for NO synthesis from L-arginine, has three isoforms: endothelial NOS (eNOS), neuronal NOS (nNOS), and inducible NOS (iNOS) [6,7]. Commonly, macrophages express iNOS in response to inflammatory mediators such as lipopolysaccharide (LPS) 
and interferon (IFN)- $\gamma$; however, eNOS and nNOS are expressed constitutively [8,9]. NO production mediates many diseases such as obesity [10], carcinogenesis [11], atherosclerosis [12], inflammation [12], and diabetes [12]. Therefore, a decrease in NO production by iNOS inhibition has therapeutic potential in various inflammatory conditions [13].

Heme oxygenase $(\mathrm{HO})$ is an important enzyme responsible for maintaining intracellular heme levels. $\mathrm{HO}$ exists as three isoforms: $\mathrm{HO}-1, \mathrm{HO}-2$, and $\mathrm{HO}-3$ [14]. HO-1 is expressed in cells at low levels under no stimulation [14]. However, its expression is inducible by a variety of stimuli including oxidative stress, LPS, melatonin, transforming growth factor- $\beta 1$, and adenosine [15]. Enhancement of HO-1 expression plays an important role in cell protection [15], and HO-1 has anti-inflammatory activity, including inhibiting NO production [16]. Its expression is regulated at the transcriptional level and is related to the transcription factor nuclear factor-erythroid 2-related factor 2 (Nrf2). Nrf2 is an upstream transcription factor that modulates phase II enzyme activity [17]. Under physiological conditions, Nrf2 is sequestered by binding to Kelch-like ECH associated protein 1 (Keap1). However, upon stimulation, Nrf2 is released from Keap1 and translocated to the nucleus to induce HO-1 expression [18].

Perilla frutescens (L.) Britton is an edible plant and a popular and frequently used garnish in some Asian countries such as China, Japan, and Korea. P. frutescens has been shown previously to have detoxicant, antitussive, antibiotic, and antipyretic effects, and it is utilized in traditional medicine $[19,20]$. The biological activity of $P$. frutescens has been well investigated. Previous studies have described the qualitative and quantitative presence of flavonoids and phenolic acids such as rosmarinic acid, catechin, apigenin, luteolin, caffeic acid, and ferulic acid in P. frutescens [21,22]. Moreover, it also contains rosmarinic acid methyl ester (RAME, Figure 1a), which exerts superoxide scavenging [23], anti-allergic [24], and anti-microbial [25] activities, as well as inhibits pro-inflammatory cytokines in the lung [26]. However, the mechanism underlying the anti-inflammatory effects of RAME has not been fully defined. Therefore, the aim of the present study was to evaluate the mechanism of the anti-inflammatory effects of RAME in LPS-treated RAW 264.7 cells.

a<smiles>COC(=O)C(Cc1ccc(O)c(O)c1)OC(=O)/C=C/c1ccc(O)c(O)c1</smiles>

Rosmarinic acid methyl ester

b

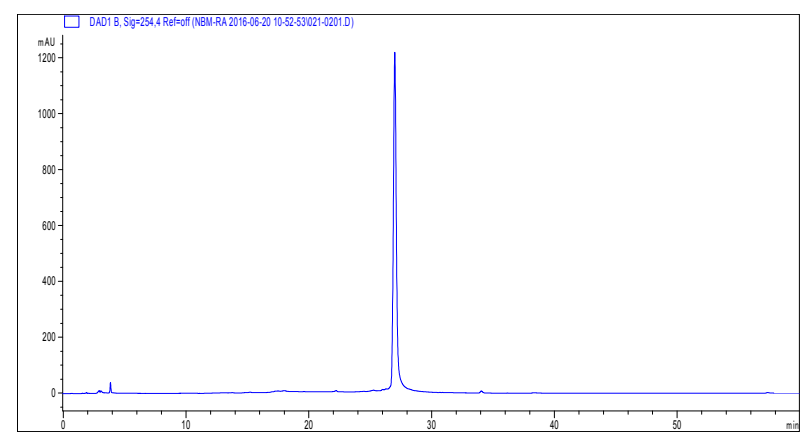

Figure 1. Cont. 
c

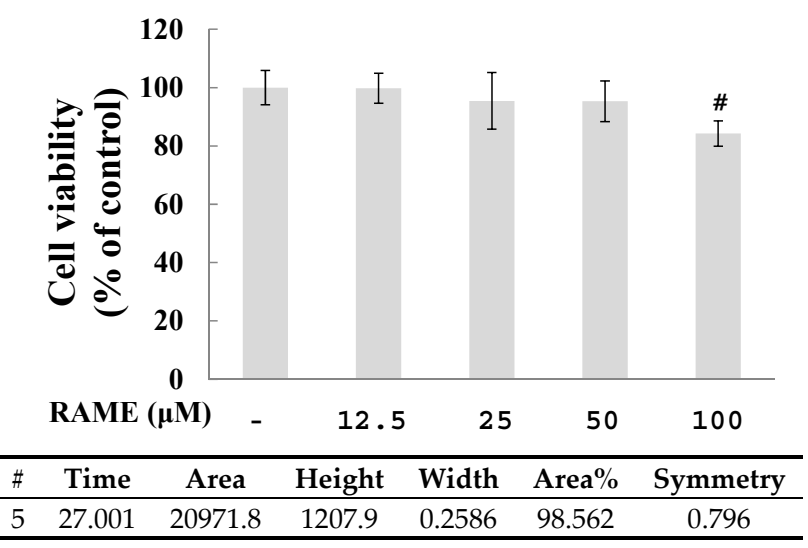

Figure 1. Chemical structure of RAME and its effects on cell viability. (a) Chemical structure of RAME; (b) Purity of RAME from a mutant cultivar of $P$. frutescens measured by HPLC analysis; (c) Cell viability. $\# p<0.05$ vs. control.

\section{Results}

\subsection{Effect of RAME on Cytotoxicity}

As shown in Figure 1b, the purity of RAME was $98.562 \%$ as determined by high performance liquid chromatography (HPLC). RAW 264.7 cells were treated with various concentrations of RAME for $24 \mathrm{~h}$, and cytotoxicity was assessed using the EZ-Cytox cell viability assay kit (Figure 1c. RAME did not exhibit cytotoxicity at $50 \mu \mathrm{M}$, but at $100 \mu \mathrm{M}$, it inhibited cell viability. Based on these results, RAME doses of $12.5,25$, and $50 \mu \mathrm{M}$ were used in this study.

\subsection{Effect of RAME on NO Production and iNOS Protein Expression Levels}

To evaluate whether RAME has anti-inflammatory properties, we investigated the effect of RAME on NO production in LPS-treated RAW 264.7 cells. The levels of NO production in the cell culture supernatant were determined using the Griess reagent. The increased NO production by LPS was significantly suppressed by pretreatment with RAME in a dose-dependent manner (Figure 2a). The $\mathrm{IC}_{50}$ value of NO inhibition was $14.25 \mu \mathrm{M}$. iNOS is responsible for NO production during inflammation [5].

We examined the effect of RAME on iNOS expression in LPS-treated RAW 264.7 cells; LPS treatment resulted in increased iNOS expression. The mRNA levels of iNOS were suppressed by treatment with RAME as measured by quantitative real-time polymerase chain reaction (PCR) (Figure $2 b$ ). Moreover, western blot analysis showed that the protein levels of iNOS were suppressed by RAME in a dose-dependent manner (Figure 2c). These results suggest that NO production was inhibited by RAME in LPS-treated RAW 264.7 cells via suppression of iNOS expression.

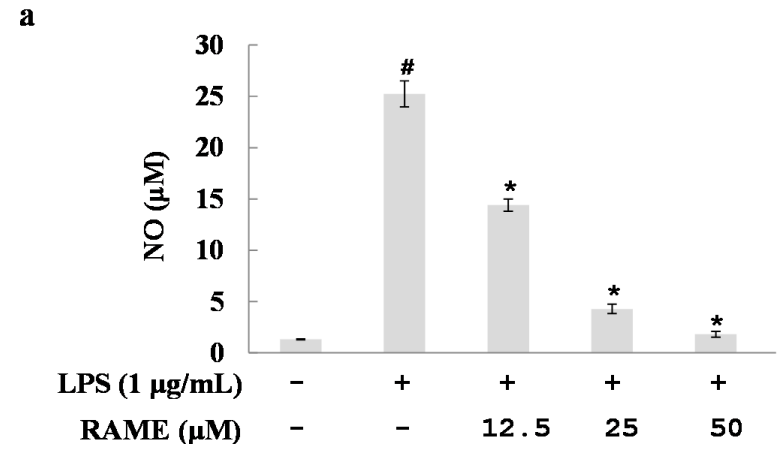

Figure 2. Cont. 
b

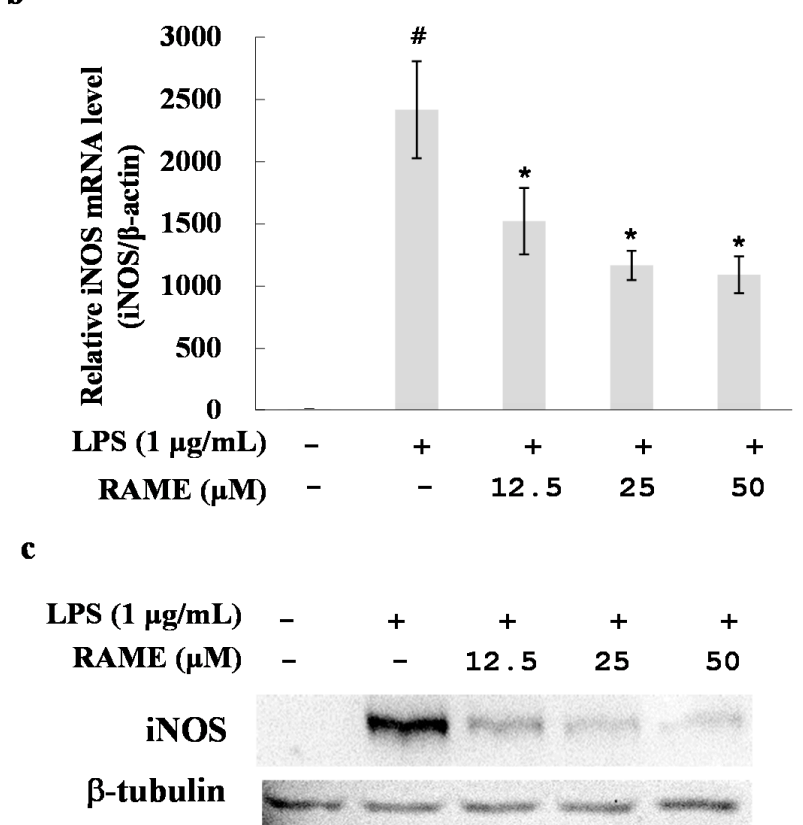

Figure 2. Effects of RAME on NO production and iNOS expression levels in RAW 264.7 cells. RAW 264.7 cells were treated with various concentrations of RAME for $2 \mathrm{~h}$ prior to incubation with LPS $(1 \mu \mathrm{g} / \mathrm{mL})$ for $18 \mathrm{~h}$. (a) Inhibition of NO production; (b) mRNA expression levels of iNOS measured by real-time PCR; (c) Protein expression levels of iNOS measured by Western blot. $\# p<0.05$ vs. control group ${ }^{*} p<0.05$ vs. LPS-treated.

\subsection{Effect of RAME on NF-kB Activation in LPS-Treated RAW 264.7 Cells}

LPS is generally activated by a myeloid differentiation primary response gene 88 (MyD88)-dependent pathway via Toll-like receptor 4 (TLR4). Activation of this MyD88-dependent pathway induces translocation of NF- $\mathrm{kB}$ to the nucleus for production of pro-inflammatory mediators including ROS, NO, and iNOS [27]. NF- $\mathrm{KB}$ is an important transcription factor involved in iNOS expression [27]. To investigate whether the effect of RAME on iNOS expression was due to inhibition of NF- $\mathrm{kB}$ activation, we examined the transcriptional activity of NF- $\mathrm{kB}$ using a luciferase assay (Figure 3).

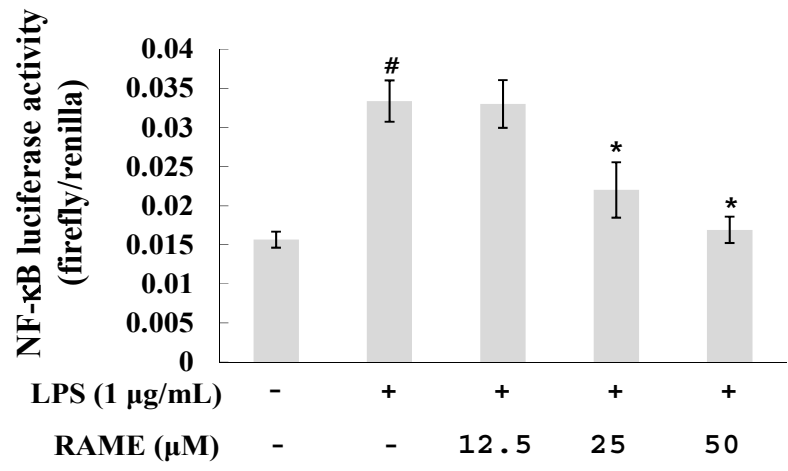

Figure 3. Effects of RAME on the NF-kB pathway. $\# p<0.05$ vs. control group, ${ }^{*} p<0.05$ vs. LPS-treated group.

NF- $\mathrm{KB}$ activity was increased in LPS-treated RAW 264.7 cells. However, its activity was reduced by treatment with RAME in a dose-dependent manner. This result indicates that RAME inhibited iNOS expression via suppression of NF-kB activation. 


\subsection{Effect of RAME on the Expression of Pro-Inflammatory Cytokines in LPS-Treated RAW 264.7 Cells}

NF- $\kappa B$ activation is related to overproduction of pro-inflammatory cytokines including IL- $1 \beta$, IL-6, IL-10, MCP-1, ROS, and NO [4,5]. To determine the effects of RAME on these pro-inflammatory cytokines, RAW 264.7 cells were incubated with various concentrations of RAME in the presence or absence of LPS for $18 \mathrm{~h}$. The mRNA levels of IL-1 $\beta$, IL-6, and IL-10 were measured by real-time PCR. As shown in Figure $4 a-c$, the mRNA levels of these pro-inflammatory cytokines were significantly reduced by treatment with RAME in a dose-dependent manner. Therefore, RAME-mediated suppression of NF- $\mathrm{KB}$ was confirmed.
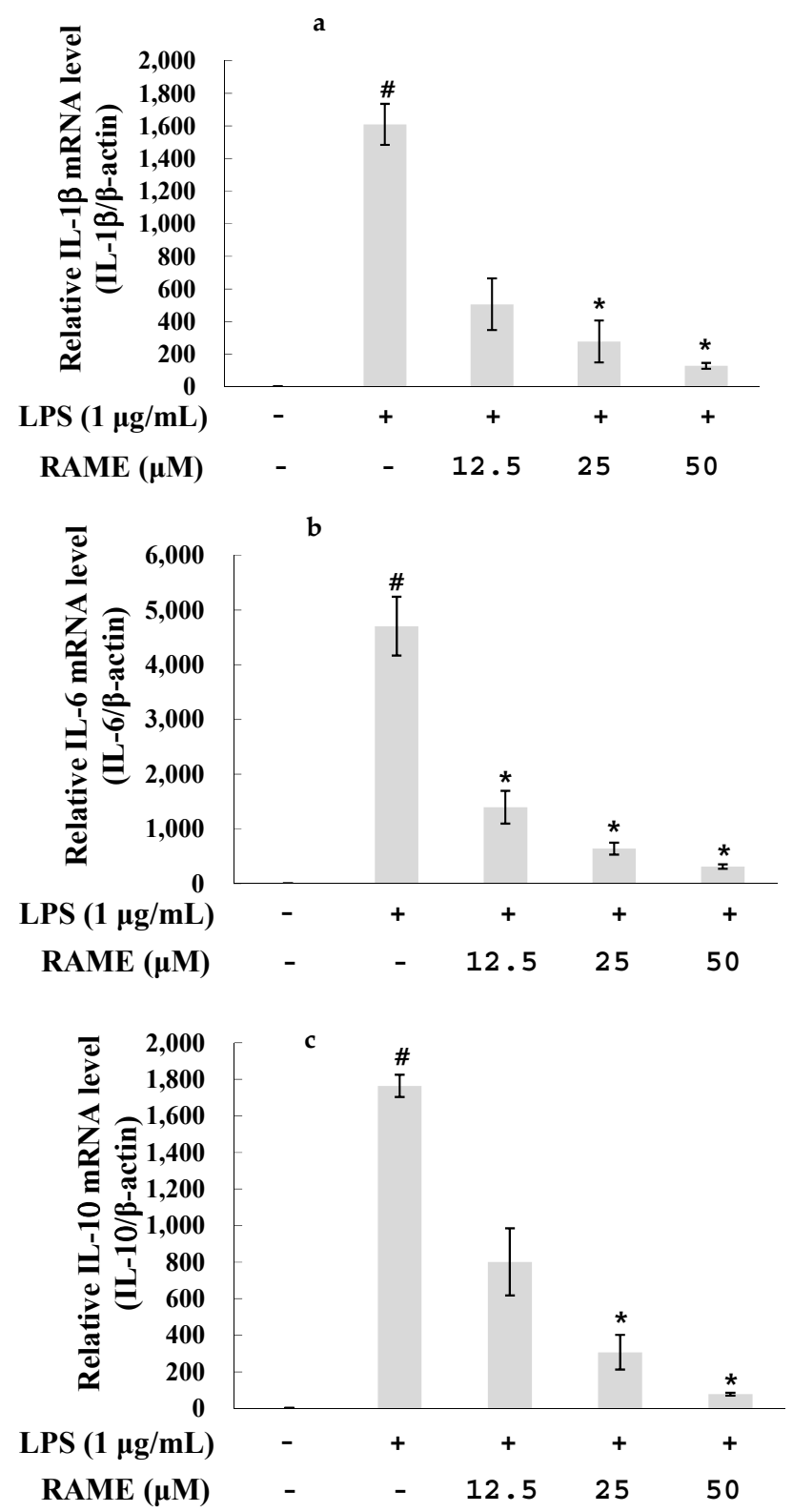

Figure 4. Effects of RAME on IL-1 $\beta$, IL-10, and IL-6 mRNA expression levels in LPS-treated RAW 264.7 cells. The expression level of pro-inflammatory cytokine genes were measured by real-time PCR. RAW 264.7 cells were treated RAME $(12.5,25$, and $50 \mu \mathrm{M})$ with LPS $(1 \mu \mathrm{g} / \mathrm{mL})$ and incubated for an additional $18 \mathrm{~h}$. mRNA expression level of genes was normalized with $\beta$-actin. (a) IL-1 $\beta$ mRNA expression level; (b) IL-6 mRNA expression level; (c) IL-10 RNA expression level. The results are presented as the means \pm SDs of three replicates of one representative experiment. $\# p<0.05 \mathrm{vs}$. control group, ${ }^{*} p<0.05$ vs. LPS-treated group. 


\subsection{Effect of RAME on the IFN- $\beta$ Pathway in LPS-Treated RAW 264.7 Cells}

IFN- $\beta$ is highly upregulated and then secreted in response to LPS [28]. Recent reports have implicated IFN- $\alpha / \beta$ as an autocrine/paracrine signal crucial for the induction of iNOS [28], and IFN- $\beta$ exhibited synergistic effects with LPS in RAW 264.7 cells, resulting in faster and greater production of NO [16]. To investigate whether RAME affects the IFN- $\beta$ pathway, we measured IFN- $\beta$ levels using an enzyme-linked immunosorbent assay (ELISA) kit. LPS-treated RAW 264.7 cells were pretreated with various concentrations of RAME, and IFN- $\beta$ production was suppressed by RAME in a dose-dependent manner (Figure 5a). This result suggests that RAME suppressed IFN- $\beta$ levels, which could be related to NO production.

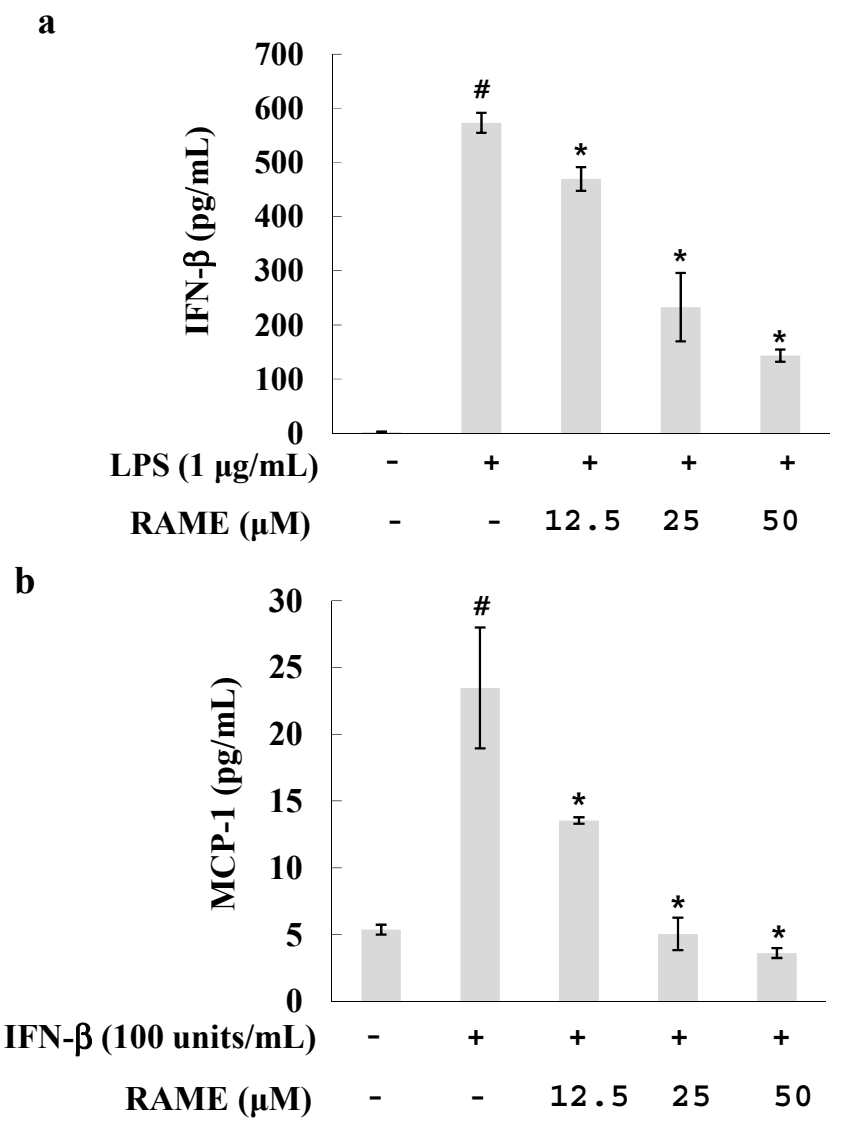

Figure 5. Effects of RAME on the IFN- $\beta$ pathway. (a) RAW 264.7 cells were treated with RAME for $2 \mathrm{~h}$ prior to incubation with LPS $(1 \mu \mathrm{g} / \mathrm{mL})$ for $4 \mathrm{~h}$. IFN- $\beta$ levels were detected in the culture supernatant using an ELISA kit. \# $p<0.05$ vs. control group, ${ }^{*} p<0.05$ vs. LPS-treated group; (b) RAW 264.7 cells were treated with various concentrations of RAME for $2 \mathrm{~h}$ prior to incubation with IFN- $\beta$ (100 units $/ \mathrm{mL}$ ) for $8 \mathrm{~h}$. MCP-1 levels were detected in the culture supernatant using an ELISA kit. $\# p<0.05$ vs. control group, ${ }^{*} p<0.05$ vs. IFN- $\beta$-treated group.

Furthermore, we investigated whether RAME could modulate the downstream pathway of IFN- $\beta$. In the MyD88-independent pathway of LPS activation, IFN- $\beta$ exerts its effects through the IFN- $\beta$ receptor, which itself does not induce NO production [16]. However, IFN- $\beta$ can induce production of the pro-inflammatory cytokine MCP-1 in RAW 264.7 cells [16]. Therefore, we examined the effect of RAME on MCP-1 levels in IFN- $\beta$-treated RAW 264.7 cells. RAW 264.7 cells were treated with various concentrations of RAME together with IFN- $\beta$ (100 units $/ \mathrm{mL}$ ). MCP-1 levels were increased by IFN- $\beta$ but suppressed by RAME in a dose-dependent manner (Figure $5 b$ ). These results suggest that RAME mediated the upstream and downstream pathways of IFN- $\beta$ production in LPS-treated RAW 264.7 cells. 


\subsection{Effect of RAME on HO-1 Induction and Nrf2 Activation}

HO-1 plays a critical role in the regulation of inflammation as it protects macrophages from ROS and helps inhibit NO production in LPS-treated RAW 264.7 cells [29]. We investigated the effect of RAME on HO-1 induction. RAME led to an increase in the mRNA and protein expression levels of HO-1. As shown in Figure 6b, RAME increased HO-1 expression in a dose-dependent manner, with a maximal increase after $6 \mathrm{~h}$ of treatment (Figure 6a).

Generally, the transcription factor Nrf2 translocates to the nucleus to induce expression of HO-1 in RAW 264.7 cells [18]. We found that RAME increased the translocation of Nrf2 to the nucleus (Figure 6c).
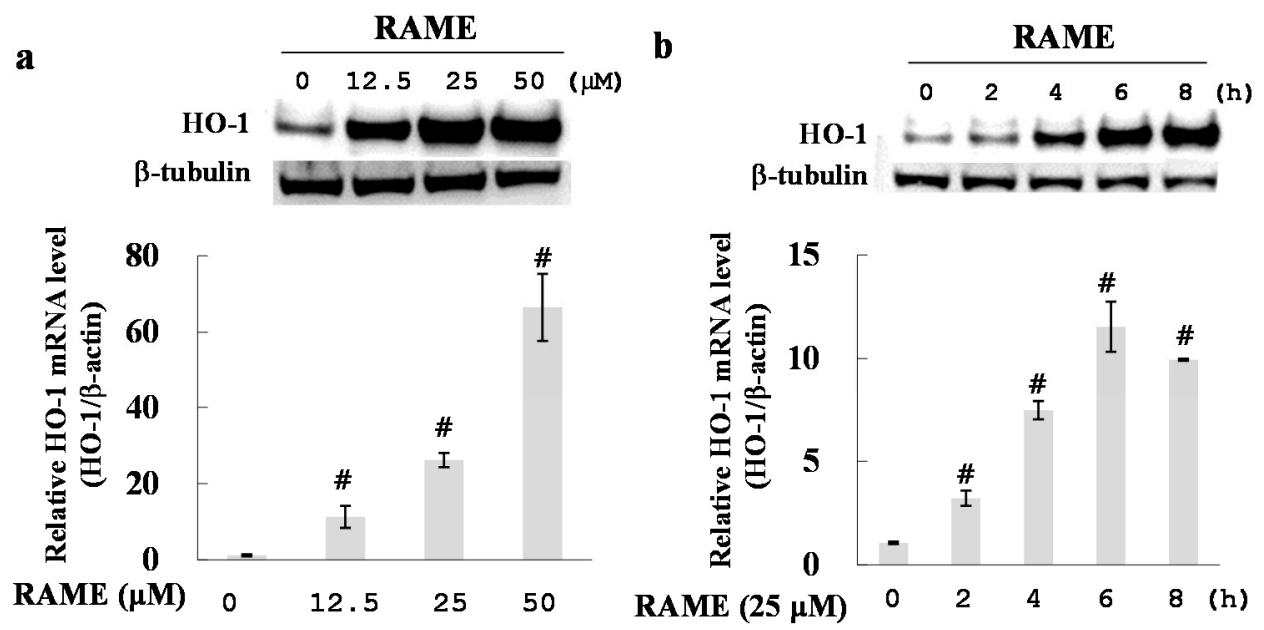

c

d
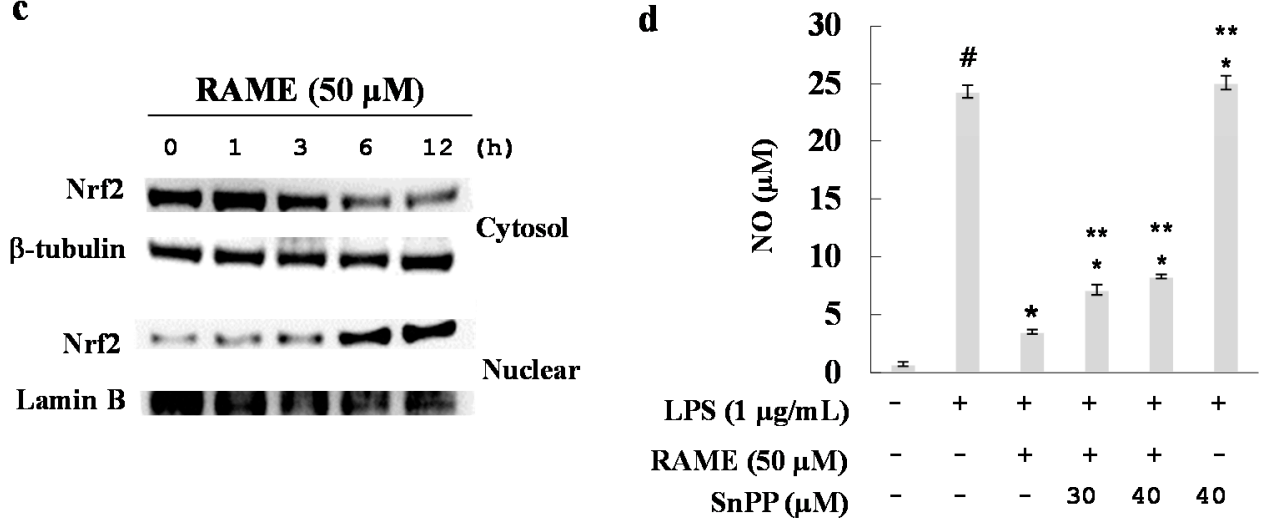

Figure 6. Effects of RAME on HO-1 expression. (a) RAW 264.7 cells were incubated with various concentrations of RAME for $6 \mathrm{~h}$. The HO-1 mRNA expression level was determined by quantitative real-time PCR. HO-1 protein expression levels were measured by western blot analysis. \# $p<0.05$ vs. control group; (b) RAW 264.7 cells were treated with $25 \mu \mathrm{M}$ RAME for $0,2,4,6$ and $8 \mathrm{~h}$. Total RNA was isolated and used to measure HO-1 mRNA expression levels by quantitative real-time PCR. $\# p<0.05$ vs. control group; (c) Cytosolic and nuclear protein fractions were extracted after treatment with RAME $(50 \mu \mathrm{M})$ for $0,1,3,6$ and $12 \mathrm{~h}$. Protein levels were normalized to those of $\beta$-tubulin and lamin B; (d) RAW 264.7 cells were treated with either RAME or RAME plus SnPP, an HO-1 inhibitor, for $2 \mathrm{~h}$ prior to incubation with LPS $(1 \mu \mathrm{g} / \mathrm{mL})$ for $18 \mathrm{~h}$. \# $p<0.05 \mathrm{vs}$. control group, ${ }^{*} p<0.05 \mathrm{vs}$. LPS-treated group and ${ }^{* *} p<0.05$ vs. LPS + RAME group.

To investigate whether HO-1 induction is responsible for the RAME-mediated inhibition of LPS-induced NO production, cells were treated with LPS and RAME in the presence of tin protoporphyrin (SnPP), a specific inhibitor of $\mathrm{HO}-1$, and NO levels were measured. SnPP alone did not significantly affect LPS-stimulated NO production; however, it restored RAME-mediated 
suppression of NO production in a dose-dependent manner (Figure 6d). These results suggest that HO-1 induced by RAME was involved in the RAME-induced inhibition of NO production.

\section{Discussion}

In previous studies, several compounds isolated from $P$. frutescens were evaluated for their potential biological activities [30,31]. The anti-inflammatory effect of rosmarinic acid (RA) has been reported in several papers $[21,32,33]$. RA had anti-inflammatory activity through the suppression of activation of ERK, JNK, p38, and NF- $\mathrm{kB}$ [32]. Furthermore, RA inhibited expression of cyclooxygenase-2 (COX-2) in LPS-treated RAW 264.7 cells [33]. Even if RAME had similar anti-inflammatory effect with RA such as suppression of NF-kB activation, RAME did not affect the expression of COX-2 in LPS-treated RAW 264.7 cells (data not shown). Therefore, those two compounds have different anti-inflammatory mechanisms. In this study, we investigated a mutant cultivar of $P$. frutescens obtained via mutagenesis by $\gamma$-rays [34]. Specifically, we examined the anti-inflammatory mechanism of RAME isolated from this mutant in LPS-treated RAW 264.7 cells. The purity of the isolated RAME was $98.562 \%$, as determined with HPLC analysis (Figure 1b). The anti-inflammatory activity of RAME was determined under non-toxic concentrations (Figure 1c). RAME suppressed NO production by inhibiting iNOS expression in LPS-treated RAW 264.7 cells (Figure 2). Therefore, we suggest that RAME exerts important anti-inflammatory activity by inhibiting iNOS expression.

LPS of gram-negative bacteria is recognized by TLR4. LPS activates two pathways: (1) the MyD88-dependent pathway and (2) the TIR domain-containing adaptor protein (TRIF)-dependent pathway [35]. Upon activation, MyD88 recruits IL-1 receptor-associated kinase (IRAK) family members, including IRAK1, IRAK2, IRAK4, and IRAK-M. IRAK4 is sequentially phosphorylated, leading to its dissociation from MyD88, which activates the TNF receptor-associated factor 6 (TRAF6) [36]. TRAF6 subsequently activates transforming growth factor- $\beta$-activated protein kinase 1 (TAK1), which is a member of the MAP kinase family [37]. TAK1 activates the IKK complex and MAP kinases, resulting in the translocation of NF- $\mathrm{kB}$ and activator protein- 1 to the nucleus. Translocation of NF- $\mathrm{kB}$ results in the production of inflammatory cytokines [36]. Much research has demonstrated that inhibiting the production of pro-inflammatory mediators via the NF- $\mathrm{KB}$ and MAPK pathways suppresses the inflammatory response [38-40]. Our results suggest that RAME suppresses iNOS expression via the NF-kB pathway (Figure 3). LPS can induce pro-inflammatory cytokines, including IL-6, IL-10, IL-1 $\beta$, and MCP-1, in macrophages [41,42]. We showed that RAME significantly inhibited the production of IL-6, IL-10, and IL-1 $\beta$ in LPS-treated RAW 264.7 cells (Figure 4a-c). These findings confirm RAME-mediated inhibition of NO production via the MyD88-dependent pathway by suppression of anti-inflammatory cytokines and NF- $\mathrm{kB}$ activation.

The TRIF-dependent pathway is important in IFN- $\beta$ production. TRIF interacts with TANK-binding kinase-1, which together with IKKi, mediates the phosphorylation of interferon regulatory transcription factor 3. Moreover, TRIF activates NF- $\mathrm{kB}$ and MAPK through TRAF6 and receptor interacting protein 1 . These pathways are required for the induction of IFN- $\beta$ [35]. IFN- $\beta$ does not exert its effect through TLR4 but rather through the IFN- $\beta$ receptor. IFN- $\beta$ cannot induce NO production alone but rather acts in synergy with LPS [16]. When we treated RAW 264.7 cells with LPS and IFN- $\beta$, NO was produced at a faster rate and higher levels than when treated with LPS alone. IFN- $\beta$ alone induced the production of MCP-1 in RAW 264.7 cells [16]. This increase was reduced by treatment with RAME (Figure $5 b$ ). These findings indicate that RAME suppressed the upstream and downstream pathways of IFN- $\beta$ in RAW 264.7 cells. Moreover, the RAME-mediated inhibition of IFN- $\beta$ may be involved in the reduction of NO production.

LPS rapidly increases ROS levels in macrophages and directly damages DNA and induces excessive inflammatory factors and cytokines [41]. HO-1 is important for the protection of macrophages from ROS and has recently become a popular target for the production of antioxidants. Nrf2 is an upstream mediator of antioxidant response element-dependent phase II enzyme expression, including HO-1 [43]. An inactivated form of Nrf2 exists in the cytoplasm, bound to Kelch-like ECH-associated 
protein 1 (Keap1). However, upon stimulation, Nrf2 dissociates from Keap1 and translocates to the nucleus to induce HO-1 expression [43]. We found that HO-1 mRNA and protein expression levels were increased by RAME via translocation of Nrf2 to the nucleus (Figure 6a-c). Furthermore, the inhibitory effect of RAME on NO production in LPS-treated RAW 264.7 cells was attenuated by treatment with SnPP, a specific HO-1 inhibitor, in a dose dependent manner (Figure 6d). Taken together, these results suggest that RAME-induced HO-1 expression was caused by the translocation of Nrf2, which may be related to NO production. The exact mechanism of RAME-induced Nrf2 translocation should be investigated in future studies.

These results suggest that RAME had anti-inflammatory activities through the MyD88-dependent pathway and -independent pathways. At this point, there is a possibility that RAME could interrupt LPS/TLR4-mediated signaling [44] directly. However, RAME also affected TLR4-independent pathways [15] for anti-inflammatory activity. We found that RAME induced HO-1 expression for inhibition of NO production via the TLR4-independent pathway. Furthermore, RAME inhibited MCP-1 production in IFN- $\beta$-treated RAW 264.7 cells (Figure 7). The production of MCP-1 was induced via IFN- $\beta /$ IFNR pathway in IFN- $\beta$-treated RAW 264.7 cells [16]. Therefore, RAME suppressed NO production via additional anti-inflammatory pathway except TLR4. Based on these results, RAME should be considered a potential anti-inflammatory agent for the treatment of inflammatory diseases.

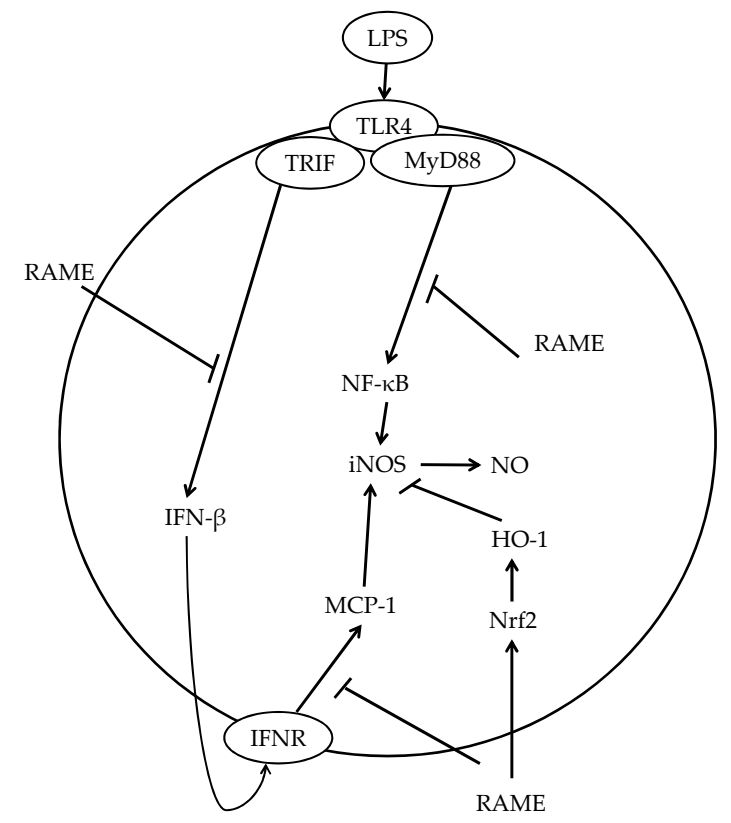

Figure 7. Possible model for the inhibition of iNOS or NO production by RAME in LPS-treated RAW 264.7 cells.

\section{Materials and Methods}

\subsection{General Procedures}

The 1D NMR experiment was performed on a JNM-ECA 500MHz NMR instrument (JEOL Ltd., Tokyo, Japan). Thin-layer chromatographic (TLC) analysis was performed on Kieselgel 60 F254 (Merck, Darmstadt, Germany), with visualization under UV light (254 and $365 \mathrm{~nm}$ ) and 10\% (v/v) sulfuric

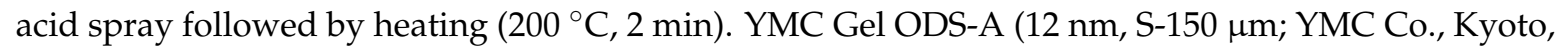
Japan), and Sephadex LH-20 (Pharmacia Co., Uppsala, Sweden) were used for column chromatography (CC). Analytical HPLC was carried out on an Agilent 1100 series system (Agilent Technologies Co., Santa Clara, CA, USA) equipped with a YMC-Triart C18 column $(5 \mu \mathrm{m}, 250 \mathrm{~mm} \times 4.6 \mathrm{~mm}$, YMC Co. $)$. 


\subsection{Materials}

The leaves of the mutant cultivar of $P$. frutescens were collected by the radiation breeding research team of the Korea Atomic Energy Research Institute [32]. The leaves were air-dried, pulverized, and stored at $4^{\circ} \mathrm{C}$ before extraction. Dulbecco's modified Eagle's medium (DMEM), fetal bovine serum (FBS), and penicillin-streptomycin were purchased from Hyclone (Logan, UT, USA). LPS, dimethyl sulfoxide (DMSO), Griess reagent, and protease inhibitor cocktail were purchased from Sigma-Aldrich (St. Louis, MO, USA). Opti-MEMI, goat anti-rabbit IgG horseradish peroxidase (HRP)-conjugated antibody, and Lipofectamine 2000 were purchased from Invitrogen (Carlsbad, CA, USA). The HO-1 inhibitor SnPP was purchased from Porphyrin Products Inc. (Logan, UT, USA). The RNeasy kit was purchased from QIAGEN (Valencia, CA, USA), the EZ-Cytox Cell Viability assay kit from DAEIL Lab (Seoul, Korea), and the 1st Strand cDNA Synthesis kit and SYBR premix from Takara Bio Inc. (Kyoto, Japan). The NP40 cell lysis buffer was purchased from Biosource (San Jose, CA, USA). The rabbit anti-iNOS polyclonal antibody was purchased from Cell Signaling Technology (Danvers, MA, USA). The rabbit polyclonal antibodies against beta-tubulin, HO-1, Lamin B, and Nrf2 were purchased from Santa Cruz Biotechnology (Santa Cruz, CA, USA). The ELISA kits for MCP-1 and IFN- $\beta$ were purchased from R\&D System (Minneapolis, MN, USA).

\subsection{Extraction and Isolation}

Dried leaves $(1.2 \mathrm{~kg})$ of the mutant cultivar of $P$. frutescens were extracted twice with $100 \%$ methanol $(10 \mathrm{~L})$ at room temperature for $24 \mathrm{~h}$, and the supernatant was evaporated under vacuum using an evaporator. The methanol extract ( $200 \mathrm{~g})$ was dissolved in distilled water and partitioned three times using $n$-hexane, chloroform, ethyl acetate, and $n$-butanol. Evaporation of the solvent of the appropriate fraction under reduced pressure yielded the ethyl acetate extract (5 g), which was further fractionated on a reverse-phase (RP) silica gel column (YMC Gel ODS-A, 12 nm, S-150 $\mu$ m; YMC Co.) and eluted using 35\% methanol to give 10 fractions (PE1-PE10). PE6 (100 mg) was fractionated on a RP silica gel column and eluted using 50\% methanol to give three fractions (PE61-PE63). PE63 (100 mg) was fractionated on a Sephadex LH-20 column and eluted using 80\% methanol to yield rosmarinic acid methyl ester (RAME) as a yellowish powder $(50 \mathrm{mg})$. The purity evaluation of RAME was determined by analytical HPLC ( 0 min, acetonitrile-water, 5:95; $45 \mathrm{~min}$, 95:5; flow rate $1 \mathrm{~mL} / \mathrm{min}$, detector UV $254 \mathrm{~nm}$ ). The $t_{\mathrm{R}}$ of RAME was $27.001 \mathrm{~min}$, and its purity was $98.562 \%$. Its structure was determined by analyse of its 1H-NMR data (Supplementary Materials Figure S1) as well as by comparison of its data with the published values [25]. ${ }^{1} \mathrm{H}-\mathrm{NMR}\left(\mathrm{CD}_{3} \mathrm{OD}, 500 \mathrm{MHz}\right): \delta 7.53(1 \mathrm{H}, \mathrm{d}, J=15.5 \mathrm{~Hz}, \mathrm{H}-7), 7.03(1 \mathrm{H}$, $\mathrm{d}, J=2.0 \mathrm{~Hz}, \mathrm{H}-2), 6.95(1 \mathrm{H}, \mathrm{dd}, J=8.0,2.0 \mathrm{~Hz}, \mathrm{H}-6), 6.77(1 \mathrm{H}, \mathrm{d}, J=8.0 \mathrm{~Hz}, \mathrm{H}-5), 6.69(1 \mathrm{H}, \mathrm{d}, J=2.0 \mathrm{~Hz}$, H-2' $), 6.68\left(1 \mathrm{H}, \mathrm{d}, J=8.0 \mathrm{~Hz}, \mathrm{H}-5^{\prime}\right), 6.55\left(1 \mathrm{H}, \mathrm{dd}, J=8.0,2.0 \mathrm{~Hz}, \mathrm{H}-6^{\prime}\right), 6.24(1 \mathrm{H}, \mathrm{d}, J=16.0 \mathrm{~Hz}, \mathrm{H}-8)$, $5.17\left(1 \mathrm{H}, \mathrm{dd}, J=8.0,5.4 \mathrm{~Hz}, \mathrm{H}-8^{\prime}\right), 3.67(3 \mathrm{H}, \mathrm{s}, \mathrm{OCH} 3), 3.03\left(1 \mathrm{H}, \mathrm{dd}, J=14.2,5.4 \mathrm{~Hz}, \mathrm{H}^{\prime} 7^{\prime} \mathrm{a}\right), 3.00(1 \mathrm{H}$, $\left.\mathrm{dd}, J=14.2,8.0 \mathrm{~Hz}, \mathrm{H}-7^{\prime} \mathrm{b}\right)$.

\subsection{Cell Culture}

The RAW 264.7 cell line was obtained from ATCC. RAW 264.7 cells were cultured in DMEM supplemented with 10\% FBS, 100 units/mL penicillin, and $100 \mu \mathrm{g} / \mathrm{mL}$ streptomycin and maintained in a humidified incubator at $37^{\circ} \mathrm{C}$ in $5 \%$ carbon dioxide $\left(\mathrm{CO}_{2}\right)$.

\subsection{Cytotoxicity Assay}

The EZ-Cytox cell viability assay kit was used to measure cell viability. The cells were cultured in a 96-well plate at a density of $2.0 \times 10^{5}$ cells $/ \mathrm{mL}$ for $24 \mathrm{~h}$. RAME was dissolved in DMSO and incubated with the cells at various concentrations $(12.5,25,50$, and $100 \mu \mathrm{M})$ for an additional $24 \mathrm{~h}$. After the incubation period, $10 \mu \mathrm{L}$ solution of cell viability assay kit was added to each well and incubated for $4 \mathrm{~h}$ at $37{ }^{\circ} \mathrm{C}$ and $5 \% \mathrm{CO}_{2}$. The index of cell viability was determined by measuring formazan production using a spectrophotometer (Benchmark Plus, Bio-Rad, Hercules, CA, USA) at an absorbance of $480 \mathrm{~nm}$ 
with a reference wavelength of $650 \mathrm{~nm}$. The results are presented as means \pm standard deviation (SD) of six replicates for one representative experiment.

\subsection{Nitrite Assay}

The cells were cultured in a 96-well plate at a density of $2.0 \times 10^{5}$ cells $/ \mathrm{mL}$ for $24 \mathrm{~h}$. After incubation, the cells were pretreated with various concentrations of RAME $(12.5,25$, and $50 \mu \mathrm{M})$ for $2 \mathrm{~h}$ and then treated with LPS $(1 \mu \mathrm{g} / \mathrm{mL}$, dissolved in D.W.) for an additional $18 \mathrm{~h}$. The culture supernatant $(100 \mu \mathrm{L})$ was mixed with an equal volume of Griess reagent $(100 \mu \mathrm{L})$ in a 96-well plate and incubated for $15 \mathrm{~min}$ at room temperature. The absorbance of each sample was measured at $540 \mathrm{~nm}$ using a spectrophotometer. The results are presented as means \pm SD of six replicates for one representative experiment.

\subsection{Western Blotting}

The cells were cultured in a $100 \mathrm{~mm}$ culture dish at a density of $2.0 \times 10^{5}$ cells $/ \mathrm{mL}$ for $24 \mathrm{~h}$. They were treated with RAME at various concentrations $(12.5,25$, and $50 \mu \mathrm{M})$ for $2 \mathrm{~h}$ and subsequently with LPS $(1 \mu \mathrm{g} / \mathrm{mL})$ for $1 \mathrm{~h}$ (for Nrf2 protein expression), $6 \mathrm{~h}$ (for HO-1 protein expression), or $18 \mathrm{~h}$ (for iNOS protein expression). The cells were harvested and lysed using NP40 cell lysis buffer (with $1 \mathrm{mM}$ phenylmethylsulfonyl fluoride and 1x protease inhibitor cocktail) for $30 \mathrm{~min}$ on ice, and the resulting cell extracts were centrifuged. Nuclear and cytosolic extracts were prepared using a NE-PER Nuclear and cytoplasmic extraction reagents (Pierce, Rockford, IL, USA). The protein concentration was quantified, and the proteins were separated on $10 \%$ running gels and transferred to nitrocellulose membranes. The membranes were incubated with primary antibodies (Nrf2, HO-1, iNOS, lamin B, and tubulin) at $4{ }^{\circ} \mathrm{C}$ overnight. The primary antibodies were diluted according to the manufacturer's protocol. The membranes were washed four times with TBS-T for $15 \mathrm{~min}$ and then incubated with HRP-conjugated secondary antibodies for $2 \mathrm{~h}$ on a shaker at room temperature. The membranes were then washed again, and the proteins were detected using an enhanced chemiluminescence detection system.

\subsection{Quantitative Real-Time Polymerase Chain Reaction}

The cells were cultured in a 6-well plate at a density of $2.0 \times 10^{5}$ cells $/ \mathrm{mL}$ for $24 \mathrm{~h}$. They were treated with RAME at various concentrations $(12.5,25$ and $50 \mu \mathrm{M})$ for $2 \mathrm{~h}$ and were subsequently incubated with LPS $(1 \mu \mathrm{g} / \mathrm{mL})$ for an additional $18 \mathrm{~h}$. Total RNA was isolated using the RNeasy kit according to the manufacturer's protocol. The 1st Strand cDNA Synthesis kit was used for reverse transcription according to the manufacturer's protocol. SYBR was used for real time PCR amplification for iNOS, HO-1, IL-10, IL-6, IL-1 $\beta$ and $\beta$-actin using the Chromo 4 RT-PCR detection system (Table 1).

Table 1. Primer sequences used in quantitative real-time PCR.

\begin{tabular}{ccc}
\hline Primers & Forward & \multicolumn{1}{c}{ Reverse } \\
\hline IL-1 $\beta$ & GAGAATGACCTGTTCTTTGAAGTTGAC & TGAAGCTGGATGCTCTCATCAG \\
IL-6 & GTTCTCTGGGAAATCGTGGAA & GCAAGTCCATCATCGTTGTTC \\
IL-10 & GACAACATACTGCTAACCGACTCC & TTCACCTGCTCCACTGCCTTG \\
HO-1 & TTACCTTCCCGAACATCGAC & GCATAAATTCCCACTGCCAC \\
iNOS & TCCTACACACCAAACTGTGTGC & CTCCAATCTCTGCCTATCCGTCTC \\
$\beta$-actin & TGAGAGGGAAATCGTGCGTGAC & GCTCGTTGCCAATAGTGATGACC \\
\hline
\end{tabular}

Gene expression was compared with that of $\beta$-actin and evaluated by the comparative CT threshold protocol using the Bio-Rad Genex-Gene Expression Macro software tool [45]. The results are presented as means \pm SDs of three replicates for one representative experiment. 


\subsection{Luciferase Assay}

RAW 264.7 cells were cultured in a 6-well plate at a density of $4.0 \times 10^{5}$ cells $/ \mathrm{mL}$ for $24 \mathrm{~h}$. The pNF-kB-Luc reporter plasmid and the pRL-TK plasmid were transfected into RAW 264.7 cells using Lipofectamine according to the manufacturer's instructions. After transfection, the cells were treated with various concentrations of $\operatorname{RAME}(12.5,25$ and $50 \mu \mathrm{M})$ for $2 \mathrm{~h}$ and were subsequently incubated with LPS $(1 \mu \mathrm{g} / \mathrm{mL})$ for an additional $24 \mathrm{~h}$. The cells were collected, and a dual-luciferase reporter assay system was used. The results are presented as means \pm SD of three replicates for one representative experiment.

\subsection{Measurement of IFN- $\beta$ and MCP-1 Levels}

The cells were cultured in a 6-well plate at a density of $2.0 \times 10^{5}$ cells $/ \mathrm{mL}$ for $24 \mathrm{~h}$. After incubation, the cells were pretreated with various concentrations of RAME $(12.5,25$ and $50 \mu \mathrm{M})$ for $2 \mathrm{~h}$ and then incubated with LPS $(1 \mu \mathrm{g} / \mathrm{mL})$ for an additional $4 \mathrm{~h}$ for measured IFN- $\beta$. RAW 264.7 cells were pretreated with RAME for prior to the addition of IFN- $\beta$ (100 unit $/ \mathrm{mL}$ ) and incubated for an additional $8 \mathrm{~h}$ for measured MCP-1. The levels of IFN- $\beta$ and MCP-1 proteins in the cell supernatant were measured using an ELISA kit according to the manufacturer's protocol. The results are presented as means $\pm \mathrm{SD}$ of three replicates for one representative experiment.

\subsection{Statistical Analysis}

All data are presented as means $\pm \mathrm{SD}$. The differences in means between the treated and untreated groups were determined using the Student's $t$ test. A $p$ value $<0.05$ was considered to indicate statistical significance. $\# p<0.05 \mathrm{vs}$. control group, ${ }^{*} p<0.05 \mathrm{vs}$. LPS-treated group and ${ }^{* *} p<0.05 \mathrm{vs}$. LPS + RAME group.

\section{Conclusions}

In this study, we investigated the underlying mechanism underlying the anti-inflammatory effects of RAME, isolated from the P. frutescens mutant, in RAW 264.7 cells. RAME inhibited NO production via suppression of iNOS expression, which was mediated by inhibition of NF- $\mathrm{kB}$ activation. It also inhibited the upstream and downstream pathways of IFN- $\beta$ production. In addition, RAME induced HO-1 expression via Nrf2 activation, which contributed to its anti-inflammatory activity (Figure 7).

These results suggest that RAME inhibited NO production via both MyD88-dependent pathway and -independent pathways, as well as via the induction of HO-1 expression. RAME should be considered a potential anti-inflammatory agent for the treatment of inflammatory diseases.

Supplementary Materials: Supplementary materials can be accessed at: http://www.mdpi.com/1420-3049/21/ 8/1083/s1.

Acknowledgments: This work was supported by the R\&D program of the Korea Atomic Energy Research Institute and the National Research Foundation of Korea (NRF) grant funded by the Korea government (MSIP) (No. 2012M2A2A6010575).

Author Contributions: Chang Hyun Jin designed the research; Yangkang So performed the experiments and analyzed the data; Yangkang So and Chang Hyun Jin wrote the paper; Seung Young Lee isolated RAME and confirmed its structure; Ah-Reum Han confirmed the spectroscopic data of RAME, evaluated its purity, and assisted the revision of the manuscript; Jin-Baek Kim provided the plant; Hye Gwang Jeong verified and improved the final results; All authors read and approved the final manuscript.

Conflicts of Interest: The authors declare no conflict of interest.

\section{References}

1. Kim, K.N.; Heo, S.J.; Yoon, W.J.; Kang, S.M.; Ahn, G.; Yi, T.H.; Jeon, Y.J. Fucoxanthin inhibits the inflammatory response by suppressing the activation of NF- $\mathrm{KB}$ and MAPKs in lipopolysaccharide-induced RAW 264.7 macrophages. Eur. J. Pharmacol. 2010, 649, 369-375. [PubMed] 
2. Guzik, T.J.; Korbut, R.; Adamek-Guzik, T. Nitric oxide and superoxide in inflammation and immune regulation. J. Physiol. Pharmacol. 2003, 54, 469-487. [PubMed]

3. Nathan, C. Points of control in inflammation. Nature 2002, 420, 846-852. [PubMed]

4. Walsh, N.C.; Crotti, T.N.; Goldring, S.R.; Gravallese, E.M. Rheumatic diseases: The effects of inflammation on bone. Immunol. Rev. 2005, 208, 228-251. [PubMed]

5. Lee, H.J.; Hyun, E.A.; Yoon, W.J.; Kim, B.H.; Rhee, M.H.; Kang, H.K.; Cho, J.Y.; Yoo, E.S. In vitro anti-inflammatory and anti-oxidative effects of Cinnamomum camphora extracts. J. Ethnopharmacol. 2006, 103, 208-216. [PubMed]

6. Lowenstein, C.J.; Hill, S.L.; Lafond-Walker, A.; Wu, J.; Allen, G.; Landavere, M.; Rose, N.R.; Herskowitz, A. Nitric oxide inhibits viral replication in murine myocarditis. J. Clin. Investig. 1996, 97, 1837-1843. [PubMed]

7. Palmer, R.M.; Ashton, D.S.; Moncada, S. Vascular endothelial cells synthesize nitric oxide from L-arginine. Nature 1988, 333, 664-666. [CrossRef] [PubMed]

8. Yun, H.Y.; Dawson, V.L.; Dawson, T.M. Neurobiology of nitric oxide. Crit. Rev. Neurobiol. 1996, 10, $291-316$. [CrossRef] [PubMed]

9. Moncada, S.; Palmer, R.M.; Higgs, E.A. Nitric oxide: Physiology, pathophysiology, and pharmacology. Pharmacol. Rev. 1991, 43, 109-142. [PubMed]

10. Mordan, L.J.; Burnett, T.S.; Zhang, L.X.; Tom, J.; Cooney, R.V. Inhibitors of endogenous nitrogen oxide formation block the promotion of neoplastic transformation in C3H10T1/2 fibroblasts. Carcinogenesis 1993, 14, 1555-1559. [CrossRef] [PubMed]

11. Ohshima, H.; Bartsch, H. Chronic infections and inflammatory processes as cancer risk factors: Possible role of nitric oxide in carcinogenesis. Mutat. Res. 1994, 305, 253-264. [CrossRef]

12. Kröncke, K.D.; Fehsel, K.; Kolb-Bachofen, V. Inducible nitric oxide synthase in human diseases. Clin. Exp. Immunol. 1998, 113, 147-156. [CrossRef] [PubMed]

13. Pan, C.H.; Kim, E.S.; Jung, S.H.; Nho, C.W.; Lee, J.K. Tectorigenin inhibits IFN-gamma/LPS-induced inflammatory responses in murine macrophage RAW 264.7 cells. Arch. Pharm. Res. 2008, 31, 1447-1456. [CrossRef] [PubMed]

14. Sikorski, E.M.; Hock, T.; Hill-Kapturczak, N.; Agarwal, A. The story so far: Molecular regulation of the heme oxygenase-1 gene in renal injury. Am. J. Physiol. Renal Physiol. 2004, 86, F425-F441. [CrossRef] [PubMed]

15. Camhi, S.L.; Alam, J.; Wiegand, G.W.; Chin, B.Y.; Choi, A.M. Transcriptional activation of the HO-1 gene by lipopolysaccharide is mediated by $5^{\prime}$ distal enhancers: Role of reactive oxygen intermediates and AP-1. Am. J. Respir. Cell Mol. Biol. 1998, 18, 226-234. [CrossRef] [PubMed]

16. Jin, C.H.; Lee, H.J.; Park, Y.D.; Choi, D.S.; Kim, D.S.; Kang, S.Y.; Seo, K.I.; Jeong, I.Y. Isoegomaketone inhibits lipopolysaccharide-induced nitric oxide production in RAW 264.7 macrophages through the heme oxygenase-1 induction and inhibition of the interferon-beta-STAT-1 pathway. J. Agric. Food Chem. 2010, 58, 860-867. [CrossRef] [PubMed]

17. Alam, J.; Stewart, D.; Touchard, C.; Boinapally, S.; Choi, A.M.; Cook, J.L. Nrf2, a Cap'n'Collar transcription factor, regulates induction of the heme oxygenase-1 gene. J. Biol. Chem. 1999, 274, 26071-26078. [CrossRef] [PubMed]

18. Johnson, J.A.; Johnson, D.A.; Kraft, A.D.; Calkins, M.J.; Jakel, R.J.; Vargas, M.R.; Chen, P.C. The Nrf2-ARE pathway: An indicator and modulator of oxidative stress in neurodegeneration. Ann. N. Y. Acad. Sci. 2008, 1147, 61-69. [CrossRef] [PubMed]

19. Liu, J.H.; Steigel, A.; Reininger, E.; Bauer, R. Two new prenylated 3-benzoxepin derivatives ascyclooxygenase inhibitors from Perilla frutescens var. acuta. J. Nat. Prod. 2000, 63, 403-405. [CrossRef] [PubMed]

20. Nakamura, Y.; Ohto, Y.; Murakami, A.; Ohigashi, H. Superoxide scavenging activity of rosmarinic acid from Perilla frutescens Britton Var. acuta f. Viridis. J. Agric. Food Chem. 1998, 46, 4545-4550. [CrossRef]

21. Osakabe, N.; Yasuda, A.; Natsume, M.; Sanbongi, C.; Kato, Y.; Osawa, T.; Yoshikawa, T. Rosmarinic acid, a major polyphenolic component of Perilla frutescens, reduces lipopolysaccharide (lps)-induced liver injury in D-galactosamine (D-galn) sensitized mice. Free Radic Biol. Med. 2002, 33, 798-806. [CrossRef]

22. Makino, T.; Furuta, Y.; Wakushima, H.; Fujii, H.; Saito, K.; Kano, Y. Anti-allergic effect of Perilla frutescens and its active constituents. Phytother. Res. 2003, 17, 240-243. [CrossRef] [PubMed]

23. Akyoshis, S.; Takashi, S.; Ryosuke, A.; Keisuks, S.; Kouta, N.; Chie, O.; Yoh, H.; Sadao, K.; Ueda, H.; Yamazaki, M. Toward Use of the Leaves of Perilla frutescens (L.) Britton var. Acuta Kudo (red perilla) with Japanese Dietary Pickled Plum (Umeboshi). J. Oleo Sci. 2006, 55, 413-422. 
24. Zhu, F.; Xu, Z.; Yonekura, L.; Yang, R.; Tamura, H. Antiallergic activity of rosmarinic acid esters is modulated by hydrophobicity, and bulkiness of alkyl side chain. Biosci. Biotechnol. Biochem. 2015, 79, 1178-1182. [CrossRef] [PubMed]

25. Amin, A.; Vincent, R.; Séverine, M.; Murielle, B.; Annie, S.V.; Céline, R.; Sevser, S.; François, B.; Christel, N.; Thierry, H. Rosmarinic Acid and Its Methyl Ester as Antimicrobial Components of the Hydromethanolic Extract of Hyptis atrorubens Poit. (Lamiaceae). ECAM 2013, 2013. [CrossRef]

26. Lim, H.J.; Woo, K.W.; Lee, K.R.; Lee, S.K.; Kim, H.P. Inhibition of Proinflammatory Cytokine Generation in Lung Inflammation by the Leaves of Perilla frutescens and Its Constituents. Biomol. Ther. (Seoul) 2014, 22, 62-67. [CrossRef] [PubMed]

27. Ma, J.S.; Kim, W.J.; Kim, J.J.; Kim, T.J.; Ye, S.K.; Song, M.D.; Kang, H.; Kim, D.W.; Moon, W.K.; Lee, K.H. Gold nanoparticles attenuate LPS-induced NO production through the inhibition of NF-kappaB and IFN-beta/STAT1 pathways in RAW 264.7 cells. Nitric Oxide 2010, 23, 214-219. [CrossRef] [PubMed]

28. Jacobs, A.T.; Ignarro, L.J. Lipopolysaccharide-induced expression of interferon-beta mediates the timing of inducible nitric-oxide synthase induction in RAW 264.7 macrophages. J. Biol. Chem. 2001, 276, 47950-47957. [PubMed]

29. Halasi, M.; Wang, M.; Chavan, T.S.; Gaponenko, V.; Hay, N.; Gartel, A.L. ROS inhibitor N-acetyl-L-cysteine antagonizes the activity of proteasome inhibitors. Biochem. J. 2013, 454, 201-208. [CrossRef] [PubMed]

30. Takeda, H.; Tsuji, M.; Inazu, M.; Egashira, T.; Matsumiya, T. Rosmarinic acid and caffeic acid produce antidepressive-like effect in the forced swimming test in mice. Eur. J. Pharmacol. 2002, 449, 261-267. [CrossRef]

31. Selvendiran, K.; Koga, H.; Ueno, T.; Yoshida, T.; Maeyama, M.; Torimura, T.; Yano, H.; Kojiro, M.; Sata, M. Luteolin promotes degradation in signal transducer and activator of transcription 3 in human hepatoma cells: An implication for the antitumor potential of flavonoids. Cancer Res. 2006, 66, 4826-4834. [CrossRef] [PubMed]

32. Liang, Z.; Xu, Y.; Wen, X.; Nie, H.; Hu, T.; Yang, X.; Chu, X.; Yang, J.; Deng, X.; He, J. Rosmarinic Acid Attenuates Airway Inflammation and Hyperresponsiveness in a Murine Model of Asthma. Molecules 2016, 21. [CrossRef] [PubMed]

33. Huang, N.; Hauck, C.; Yum, M.Y.; Rizshsky, L.; Widrlechner, M.P.; McCoy, J.A.; Murphy, P.A.; Dixon, P.M.; Nikolau, B.J.; Birt, D.F. Rosmarinic acid in Prunella vulgaris ethanol extract inhibits lipopolysaccharide-induced prostaglandin E2 and nitric oxide in RAW 264.7 mouse macrophages. J. Agric. Food Chem. 2009, 57, 10579-10589. [CrossRef] [PubMed]

34. Park, Y.D.; Kang, M.A.; Lee, H.J.; Jin, C.H.; Choi, D.S.; Kim, D.S.; Kang, S.Y.; Byun, M.W.; Jeong, I.Y. Inhibition of an inducible nitric oxide synthase expression by a hexane extract from Perilla frutescens cv. chookyoupjaso mutant induced by mutagenesis with gamma-ray. J. Radiat. Ind. 2009, 3, 13-18.

35. Kawai, T.; Akira, S. TLR signaling. Cell Death Differ. 2006, 13, 816-825. [CrossRef] [PubMed]

36. Sato, S.; Sugiyama, M.; Yamamoto, M.; Watanabe, Y.; Kawai, T.; Takeda, K.; Akira, S. Toll/IL-1 receptor domain-containing adaptor inducing IFN-beta (TRIF) associates with TNF receptor-associated factor 6 and TANK-binding kinase 1, and activates two distinct transcription factors, NF-kappa B and IFN-regulatory factor-3, in the Toll-like receptor signaling. J. Immunol. 2003, 171, 4304-4310. [PubMed]

37. Covert, M.W.; Leung, T.H.; Gaston, J.E.; Baltimore, D. Achieving stability of lipopolysaccharide -induced NF-kappaB activation. Science 2005, 309, 1854-1857. [CrossRef] [PubMed]

38. Shin, J.S.; Noh, Y.S.; Lee, Y.S.; Cho, Y.W.; Baek, N.I.; Choi, M.S.; Jeong, T.S.; Kang, E.; Chung, H.G.; Lee, K.T. Arvelexin from Brassica rapa suppresses NF-kB-regulated pro-inflammatory gene expression by inhibiting activation of IкB kinase. Br. J. Pharmacol. 2011, 164, 145-158. [CrossRef] [PubMed]

39. Yoon, W.J.; Moon, J.Y.; Song, G.; Lee, Y.K.; Han, M.S.; Lee, J.S.; Ihm, B.S.; Lee, W.J.; Lee, N.H.; Hyun, C.G. Artemisia fukudo essential oil attenuates LPS-induced inflammation by suppressing NF-kappaB and MAPK activation in RAW 264.7 macrophages. Food Chem. Toxicol. 2010, 48, 1222-1229. [CrossRef] [PubMed]

40. Reddy, D.B.; Reddanna, P. Chebulagic acid (CA) attenuates LPS-induced inflammation by suppressing NF-kappaB and MAPK activation in RAW 264.7 macrophages. Biochem. Biophys. Res. Commun. 2009, 381, 112-117. [CrossRef] [PubMed]

41. Han, J.M.; Lee, W.S.; Kim, J.R.; Son, J.; Kwon, O.H.; Lee, H.J.; Lee, J.J.; Jeong, T.S. Effect of 5-O-Methylhirsutanonol on nuclear factor-kappaB-dependent production of NO and expression of iNOS in lipopolysaccharide-induced RAW 264.7 cells. J. Agric. Food Chem. 2008, 56, 92-98. [CrossRef] [PubMed] 
42. Lu, C.L.; Zhu, Y.F.; Hu, M.M.; Wang, D.M.; Xu, X.J.; Lu, C.J.; Zhu, W. Optimization of astilbin extraction from the rhizome of Smilax glabra, and evaluation of its anti-inflammatory effect and probable underlying mechanism in lipopolysaccharide-induced RAW 264.7 macrophages. Molecules 2015, 20, 625-644. [CrossRef] [PubMed]

43. Zhang, B.; Hirahashi, J.; Cullere, X.; Mayadas, T.N. Elucidation of molecular events leading to neutrophil apoptosis following phagocytosis: Cross-talk between caspase 8 , reactive oxygen species, and MAPK/ERK activation. J. Biol. Chem. 2003, 278, 28443-28454. [CrossRef] [PubMed]

44. Molinaro, A.; Holst, O.; Di, L.F.; Callaghan, M.; Nurisso, A.; D’Errico, G.; Zamyatina, A.; Peri, F.; Berisio, R.; Jerala, R.; et al. Chemistry of lipid A: At the heart of innate immunity. Chemistry 2015, 21, 500-519. [CrossRef] [PubMed]

45. Canes, L.; Borghi, C.; Ciacci, C.; Fabbri, R.; Vergani, L.; Gallo, G. Bisphenol-A alters gene expression and functional parameters in molluscan hepatopancreas. Mol. Cell Endocrinol. 2007, 276, 36-44. [CrossRef] [PubMed]

Sample Availability: Not available.

(C) 2016 by the authors; licensee MDPI, Basel, Switzerland. This article is an open access article distributed under the terms and conditions of the Creative Commons Attribution (CC-BY) license (http://creativecommons.org/licenses/by/4.0/). 